\title{
In vitro culture of Neoechinorbynchus buttnerae (Acanthocephala: Neoechinorhynchidae): Influence of temperature and culture media
}

\author{
Cultivo in vitro de Neoechinorhynchus buttnerae (Acanthocephala: Neoechinorhynchidae): \\ influência da temperatura e dos meios de cultura \\ Carinne Moreira de Souza Costa ${ }^{1}$; Talissa Beatriz Costa Limaa ${ }^{1}$; Matheus Gomes da Cruz ${ }^{1}$; Daniela Volcan Almeida ${ }^{1}$; \\ Maurício Laterça Martins'; Gabriela Tomas Jerônimo ${ }^{2 *}$ [D
}

${ }^{1}$ Programa de Pós-graduação em Aquicultura, Universidade Nilton Lins, Manaus, AM, Brasil

${ }^{2}$ Laboratório Sanidade de Organismos Aquáticos - AQUOS, Departamento de Aquicultura, Universidade Federal de Santa Catarina - UFSC, Florianópolis, SC, Brasil

Received August 9, 2018

Accepted September 10, 2018

\begin{abstract}
Infection by the acantocephalan Neoechinorhynchus buttnerae is considered one of most important concerns for tambaqui fish (Colossoma macropomum) production. Treatment strategies have been the focus of several in vivo studies; however, few studies have been undertaken on in vitro protocols for parasite maintenance. The aim of the present study was to develop the best in vitro culture condition for $N$. buttnerae to ensure its survival and adaptation out of the host to allow for the testing of substances to be used to control the parasite. To achieve this, parasites were collected from naturally infected fish and distributed in 6-well culture plates under the following treatments in triplicate: $0.9 \% \mathrm{NaCl}$, sterile tank water, L-15 Leibovitz culture medium, L-15 Leibovitz + agar 2\% culture medium, RPMI 1640 culture medium, and RPMI $1640+$ agar 2\% culture medium. The plates containing the parasites were maintained at $24^{\circ} \mathrm{C}, 28^{\circ} \mathrm{C}$, and $32^{\circ} \mathrm{C}$. The RPMI $1640+$ agar $2 \%$ culture medium showed the best survival of 24 days at $24^{\circ} \mathrm{C}$. No body alterations such as swollen parasites, body deformation, dehydration and hardening were observed in the RPMI $1640+2 \%$ culture medium.
\end{abstract}

Keywords: Fish farming, tambaqui, acantocephalan, culture, survival.

\section{Resumo}

A infecção pelo acantocéfalo Neoechinorhynchus buttnerae é considerada uma das preocupaçôes mais importantes para produção de tambaqui (Colossoma macropomum). Estratégias de tratamento têm sido o foco de vários estudos in vivo; entretanto, poucos estudos foram realizados em protocolos in vitro para manutenção do parasito. O objetivo deste estudo foi desenvolver a melhor condição de cultura in vitro para $N$. buttnerae para garantir sua sobrevivência e adaptação fora do hospedeiro, a ser utilizado para teste com substâncias no controle do parasito. Para isso, os parasitos foram coletados de peixes naturalmente infectados e distribuídos em placas de cultura de 6 poços sob os seguintes tratamentos em triplicata: $0.9 \% \mathrm{NaCl}$, água estéril do tanque, meio de cultura L-15 Leibovitz, meio de cultura L-15 Leibovitz + ágar 2\%, meio de cultura RPMI 1640, e meio de cultura RPMI 1640 + ágar 2\%. As placas contendo os parasitos foram mantidos a $24^{\circ} \mathrm{C}, 28^{\circ} \mathrm{C}$, e $32^{\circ} \mathrm{C}$. O meio de cultura RPMI 1640 + ágar $2 \%$ apresentou a melhor sobrevivência de 24 dias a 24 ${ }^{\circ} \mathrm{C}$. Nenhuma alteração corporal tais como inchaço dos parasitos, deformação corporal, desidratação e endurecimento foram observados no meio de cultura RPMI 1640 + ágar 2\%.

Palavras-chave: Piscicultura, tambaqui, acantocéfalo, cultivo, sobrevivência.

\section{Introduction}

Intensive fish farming may provoke environmental alterations that favor disease outbreaks (REVERTER et al., 2014). Changes in temperature, water quality, and nutritional status are responsible for

*Corresponding author: Gabriela Tomas Jerônimo. Laboratório Sanidade de Organismos Aquáticos - AQUOS, Departamento de Aquicultura, Universidade Federal de Santa Catarina - UFSC, Rod. Admar Gonzaga, 1346, CEP 88040-900, Florianópolis, SC, Brasil. e-mail: gabrielatj@gmail.com a decrease in fish immune systems, which enhance susceptibility to infections (QUESADA et al., 2013). Among the main pathogens causing diseases in fish farms are protozoans, myxozoans, helminths, and crustaceans, which under favorable environmental conditions may reproduce or disseminate culminating in diseases (JERÔNIMO et al., 2015).

The acanthocephalan Neoechinorhynchus buttnerae (Golvan, 1956) belongs to the class Eoacanthocephala (Van Cleve, 1936), order 
Neoechinorhynchida (Ward, 1917), and family Neoechinorhynchidae (Travassos, 1917), and is an endoparasite mostly found in the intestines of their hosts (SANTOS et al., 2013). Its infection has been considered one of the most important obstacles for tambaqui (Colossoma macropomum Cuvier 1816) production in Brazil (LOURENÇO et al., 2017) and can cause economic losses (GOMES et al., 2017). This is related to a significant decrease in fish production and fish performance owing to weight loss, cachexia due to competition for the diet nutrients, as well as decreased area of intestinal absorption (JERÔNIMO et al., 2017). Moreover, the parasite attaches to the intestinal epithelium with their hooks, induces a severe inflammatory reaction, and causes dilacerations of the intestinal mucosa (JERÔNIMO et al., 2017).

Acanthocephalosis in Brazil represents an important concern due to high infections of fish in the northern region (MALTA et al., 2001; GOMES et al., 2017; LOURENÇO et al., 2017; MATOS et al., 2017). Therefore, the development of effective treatments against the parasite is urgently required. Prior to in vivo treatment, the standardization of techniques in vitro using parasites out of their hosts is strongly recommended. Both studies are required because of the metabolic dependence of the parasite in the microenvironment (POULIN \& MORAND, 2004). In the past, studies have tested the acanthocephalan culture in vitro; however, the methods have not been well-defined (NICHOLAS \& GRIGG, 1965) and, when successful, the parasites were kept alive only for a short period (POLZER \& TARASCHEWSKI, 1994).

The first trial of in vitro culture was undertaken by Gettier (1942) with 25 days survival of $N$. emydis (Leidy, 1852) which is a parasite of turtles, in $0.5 \% \mathrm{NaCl}$ added to $0.02 \% \mathrm{CaCl}_{2}$. In a later study, Van Cleave \& Ross (1944) reached 13 days survival of this parasite in $0.7 \% \mathrm{NaCl}$. The ideal culture medium for the growth of Angiostrongylus cantonensis (Chen, 1935) larvae was found to be a CBSS-based solution containing 10\% L-15 (Leibovitz) $\left(\right.$ Gibco $\left.^{\circledR}\right)$ culture medium, 10\% tryptose phosphate broth $\left(\mathrm{Gibco}^{\circledR}\right), 20 \%$ fetal calf serum, and $26 \mathrm{mM}$ of sodium bicarbonate. Fifty days after culture, $82 \%$ of the larvae had changed to the third stage (HATA \& KOJIMA, 1990). Thus, L-15 (Leibovitz) medium began to be used for growth and maintenance of cell tissue for virus diagnostics (LEIBOVITZ, 1963). As previously observed, in vitro studies with L-15 (Leibovitz) medium have demonstrated efficacy for culturing parasites (SCHRAMLOVÁ et al., 1984; HATA \& KOJIMA, 1990). Recently, this technique was improved by Buron et al. (2009) who studied the culture of acanthocephalans Moniliformis moniliformis (Bremser, 1811) Travassos, 1915, in rats for 8 days in medium enriched with glucose.

Conversely, Roswell Park Memorial Institute (RPMI) 1640 culture medium that was developed for human leukemic culture in suspension is considered adequate for use in a wide variety of mammal cells including HeLa, Jurkat, MCF-7, PC12, PBMC, astrocytes, and carcinomas, and has been widely applied in parasite culture. Kawanaka et al. (1983) observed egg hatching of Schistosoma japonicum (Katsurada, 1904) cultured in RPMI 1640 medium supplemented with $10 \%$ fetal calf serum. For fish parasites, Brázová et al. (2012) observed 3 weeks survival of the acanthocephalan Acanthocephalus lucii (Müller, 1776) and the cestode Proteocephalus (Weinland, 1858), which are both parasites of Perca fluviatilis in RPMI 1640 culture medium.
Previous studies have not evaluated the influence of temperature on parasite survival. Nevertheless, a study by Thomas (2002) stated that natural environment seasonal variations, e.g., water temperature changes, might influence the abundance of helminth parasites.

The aim of the present study was to evaluate the best culture medium and temperature for the in vitro culture of the acanthocephalan $N$. buttnerae, an important parasite of tambaqui C. macropomum in the Amazon.

\section{Material and Methods}

\section{Parasites and experimental design}

A total of 13 fish $(19.15 \pm 2.30 \mathrm{~cm} ; 138.81 \pm 52.57 \mathrm{~g})$ naturally parasitized with the acanthocephalan $N$. buttnerae were used to obtain the parasites after dissection. After the removal of parasites, they were washed in $0.9 \% \mathrm{NaCl}$ for posterior distribution in 6-well plates containing $5 \mathrm{~mL}$ of each tested solution, with 5 parasites per well. This procedure was performed under a laminar flow cabinet.

The experimental design was completely randomized and was composed of six treatments with three replicates for each treatment. These included parasites maintained in $0.9 \% \mathrm{NaCl}$, sterile tank water, L-15 (Leibovitz) culture medium, L-15 (Leibovitz) + agar 2\% culture medium, RPMI 1640 culture medium, and RPMI $1640+$ agar $2 \%$ culture medium. The plates were incubated in a B.O.D (model TE 391) at $24^{\circ} \mathrm{C}, 28^{\circ} \mathrm{C}$, and $32^{\circ} \mathrm{C}$ based on the procedure described in Oliveira \& Val (2017) taking into consideration that tambaqui inhabits waters of $25^{\circ} \mathrm{C}$ to $34^{\circ} \mathrm{C}$ mean temperature.

Parasites were observed at $24 \mathrm{~h}$ intervals because a study by Van Cleave \& Ross (1944) showed that more frequent observations of parasites are responsible for reduced survival times. During incubation, the parasites were evaluated on their movement after gently stimulus with a needle and their morphological characteristics were noted. Parasites were considered dead when no movements were seen after stimulus was applied.

\section{Culture medium preparation and description}

\section{L-15 (Leibovitz)}

The L-15 (Leibovitz) (Sigma- Aldrich ${ }^{\circledR}$ ) culture medium was prepared under a laminar flow cabinet. Previous assays with $N$. buttnerae were performed and $15.18 \mathrm{~g}$ of culture medium was diluted in $1 \mathrm{~L}$ of distilled water at $15^{\circ} \mathrm{C}$ to $20{ }^{\circ} \mathrm{C}$ for posterior filtration in a net of $0.22 \mu \mathrm{m}$ mesh. Subsequently, the medium was transferred to a sterile flask maintained in a shaker at room temperature $\left(22-24^{\circ} \mathrm{C}\right)$ for $15 \mathrm{~min}$ and stored at $4{ }^{\circ} \mathrm{C}$ in the dark until use. The L-15 medium was transferred to 6-well plates with $5 \mathrm{~mL}$ solution. Every two days, the medium was replaced with a new solution to maintain its ideal properties. $\mathrm{pH}$ was adjusted to 7.0 with the addition of $\mathrm{HCl}$ or $\mathrm{NaOH}$. 


\section{RPMI 1640}

In a laminar flow cabinet, the RPMI 1640 (Gibco ${ }^{\circledR}$ ) culture medium was transferred to a sterile container to be distributed in 6-well plates with $5 \mathrm{~mL}$ final volume. The RPMI 1640 medium uses a buffer system of sodium bicarbonate $\left(2.0 \mathrm{~g} \mathrm{~L}^{-1}\right)$ and an environment with $5 \%-10 \% \mathrm{CO}_{2}$ is required to maintain the physiological $\mathrm{pH}$

\section{Agar}

Each 6-well plate was filled with $2 \mathrm{~mL}$ solid L-15 and RPMI 1640 medium (2\% agar-agar bacteriological). Then, $5 \mathrm{~mL}$ of L-15 and RPMI 1640 medium was added.

\section{Morphological evaluation of Neoechinorhynchus buttnerae}

Under a stereo microscope (Model ZEISS ${ }^{\circledR}$ Stemi 305 Compact), morphological alterations were observed in vitro such as swollen parasites, body deformation, dehydration, hardening, and absence of movement (considered dead). These analyses are required because the physiological response of the parasites is directly related to their integrity and cylindrical shape when alive and healthy. This indicates the effects of the culture medium on the parasite body.

\section{Statistical analysis}

Parasite survival (\%) among treatments was compared using the classification register test based on the survival curve of Kaplan-Meier and the comparison of survival curves was adjusted to tests of multiple comparison performed by the log-rank test, where significant differences were considered at $\mathrm{p}<0.05$. The data were analyzed using GraphPad Prism ${ }^{\circledR}$ following the instructions of GraphPad Statistic Guide for multiple comparisons of survival curves.

\section{Results}

Temperature and culture medium directly influenced survival of parasites and provoked body morphological alterations based on the time of observation (Table 1).

According the log-rank test (Figure 1A), no significant differences among the RPMI 1640, RPMI $1640+$ agar 2\%, L-15, and L-15 + agar 2\% media treatments were observed until day 12 of observation. The best mean survival was obtained for

Table 1. Number of parasites and morphological alterations of Neoechinorhynchus buttnerae exposed to different culture medium kept at 24,28 and $32^{\circ} \mathrm{C}$ during 28 days.

\begin{tabular}{|c|c|c|c|c|c|c|c|c|c|c|}
\hline \multirow{3}{*}{ Time } & \multirow{3}{*}{ Expusore } & \multicolumn{9}{|c|}{ Number of parasites } \\
\hline & & \multicolumn{3}{|c|}{$24^{\circ} \mathrm{C}$} & \multicolumn{3}{|c|}{$28^{\circ} \mathrm{C}$} & \multicolumn{3}{|c|}{$32^{\circ} \mathrm{C}$} \\
\hline & & Alive & Swollen & Dead & Alive & Swollen & Dead & Alive & Swollen & Dead \\
\hline \multirow[t]{6}{*}{ 1day } & Tank water & 0 & 15 & 15 & 0 & 15 & 15 & 0 & 15 & 15 \\
\hline & $0.9 \% \mathrm{NaCl}$ & 13 & 0 & 2 & 13 & 0 & 2 & 13 & 0 & 2 \\
\hline & $\mathrm{L}-15$ & 15 & 0 & 0 & 13 & 0 & 2 & 15 & 0 & 0 \\
\hline & L-15 + Agar & 15 & 0 & 0 & 14 & 0 & 1 & 15 & 0 & 0 \\
\hline & RPMI 1640 & 15 & 0 & 0 & 15 & 0 & 0 & 15 & 0 & 0 \\
\hline & RPMI $1640+$ Agar & 15 & 0 & 0 & 15 & 0 & 0 & 15 & 0 & 0 \\
\hline \multirow[t]{6}{*}{5 days } & Tank water & 0 & 15 & 15 & 0 & 15 & 15 & 0 & 15 & 15 \\
\hline & $0.9 \% \mathrm{NaCl}$ & 6 & 12 & 9 & 6 & 12 & 9 & 6 & 11 & 9 \\
\hline & L-15 & 13 & 3 & 2 & 11 & 5 & 4 & 0 & 15 & 15 \\
\hline & L-15 + Agar & 13 & 1 & 2 & 10 & 4 & 5 & 0 & 15 & 15 \\
\hline & RPMI 1640 & 14 & 1 & 1 & 12 & 1 & 3 & 10 & 4 & 5 \\
\hline & RPMI $1640+$ Agar & 14 & 1 & 1 & 9 & 3 & 6 & 13 & 3 & 2 \\
\hline \multirow[t]{6}{*}{10 days } & Tank water & 0 & 15 & 15 & 0 & 15 & 15 & 0 & 15 & 15 \\
\hline & $0.9 \% \mathrm{NaCl}$ & 0 & 15 & 15 & 0 & 15 & 15 & 0 & 15 & 15 \\
\hline & L-15 & 12 & 4 & 3 & 7 & 7 & 8 & 0 & 15 & 15 \\
\hline & $\mathrm{L}-15+$ Agar & 13 & 1 & 2 & 9 & 6 & 6 & 0 & 15 & 15 \\
\hline & RPMI 1640 & 12 & 4 & 3 & 9 & 4 & 6 & 0 & 15 & 15 \\
\hline & RPMI 1640 +Agar & 13 & 1 & 2 & 8 & 4 & 7 & 0 & 15 & 15 \\
\hline \multirow[t]{6}{*}{15 days } & Tank water & 0 & 15 & 15 & 0 & 15 & 15 & 0 & 15 & 15 \\
\hline & $0.9 \% \mathrm{NaCl}$ & 0 & 15 & 15 & 0 & 15 & 15 & 0 & 15 & 15 \\
\hline & L-15 & 0 & 15 & 15 & 0 & 15 & 15 & 0 & 15 & 15 \\
\hline & L-15 + Agar & 11 & 12 & 4 & 4 & 13 & 11 & 0 & 15 & 15 \\
\hline & RPMI 1640 & 10 & 4 & 5 & 7 & 6 & 8 & 0 & 15 & 15 \\
\hline & RPMI $1640+$ Agar & 13 & 2 & 2 & 7 & 4 & 8 & 0 & 15 & 15 \\
\hline
\end{tabular}


Table 1. Continued...

\begin{tabular}{|c|c|c|c|c|c|c|c|c|c|c|}
\hline \multirow{3}{*}{ Time } & \multirow{3}{*}{ Expusore } & \multicolumn{9}{|c|}{ Number of parasites } \\
\hline & & \multicolumn{3}{|c|}{$24^{\circ} \mathrm{C}$} & \multicolumn{3}{|c|}{$28^{\circ} \mathrm{C}$} & \multicolumn{3}{|c|}{$32^{\circ} \mathrm{C}$} \\
\hline & & Alive & Swollen & Dead & Alive & Swollen & Dead & Alive & Swollen & Dead \\
\hline \multirow[t]{6}{*}{20 days } & Tank water & 0 & 15 & 15 & 0 & 15 & 15 & 0 & 15 & 15 \\
\hline & $0.9 \% \mathrm{NaCl}$ & 0 & 15 & 15 & 0 & 15 & 15 & 0 & 15 & 15 \\
\hline & L-15 & 0 & 15 & 15 & 0 & 15 & 15 & 0 & 15 & 15 \\
\hline & L-15 + Agar & 0 & 15 & 15 & 0 & 15 & 15 & 0 & 15 & 15 \\
\hline & RPMI 1640 & 8 & 10 & 7 & 2 & 13 & 13 & 0 & 15 & 15 \\
\hline & RPMI $1640+$ Agar & 11 & 5 & 4 & 0 & 15 & 15 & 0 & 15 & 15 \\
\hline \multirow[t]{6}{*}{25 days } & Tank water & 0 & 15 & 15 & 0 & 15 & 15 & 0 & 15 & 15 \\
\hline & $0.9 \% \mathrm{NaCl}$ & 0 & 15 & 15 & 0 & 15 & 15 & 0 & 15 & 15 \\
\hline & L-15 & 0 & 15 & 15 & 0 & 15 & 15 & 0 & 15 & 15 \\
\hline & L-15 + Agar & 0 & 15 & 15 & 0 & 15 & 15 & 0 & 15 & 15 \\
\hline & RPMI 1640 & 0 & 15 & 15 & 2 & & 13 & 0 & 15 & 15 \\
\hline & RPMI 1640 +Agar & 0 & 15 & 15 & 0 & 15 & 15 & 0 & 15 & 15 \\
\hline \multirow[t]{6}{*}{28 days } & Tank water & 0 & 15 & 15 & 0 & 15 & 15 & 0 & 15 & 15 \\
\hline & $0.9 \% \mathrm{NaCl}$ & 0 & 15 & 15 & 0 & 15 & 15 & 0 & 15 & 15 \\
\hline & L-15 & 0 & 15 & 15 & 0 & 15 & 15 & 0 & 15 & 15 \\
\hline & L-15 + Agar & 0 & 15 & 15 & 0 & 15 & 15 & 0 & 15 & 15 \\
\hline & RPMI 1640 & 0 & 15 & 15 & 0 & 15 & 15 & 0 & 15 & 15 \\
\hline & RPMI $1640+$ Agar & 0 & 15 & 15 & 0 & 15 & 15 & 0 & 15 & 15 \\
\hline
\end{tabular}
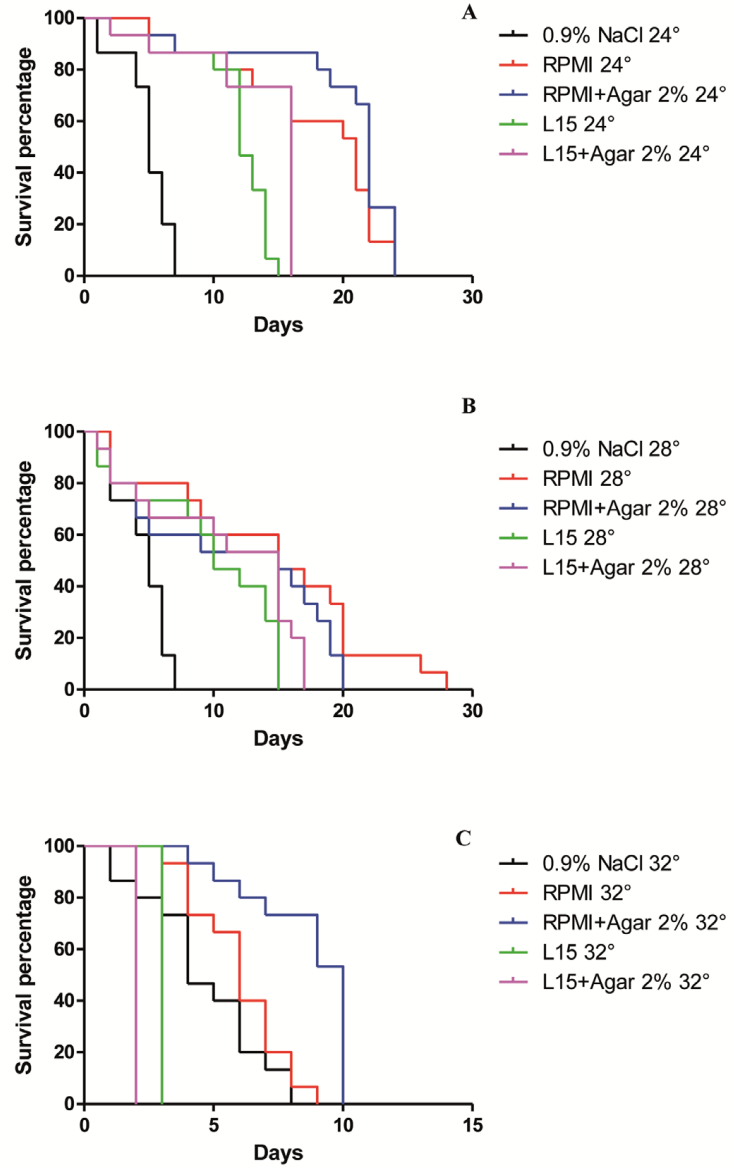

Figure 1. Survival percentage of Neoechinorhynchus buttnerae in relation to exposition time (days) exposed to different culture medium at $24^{\circ} \mathrm{C}(\mathrm{A}), 28^{\circ} \mathrm{C}(\mathrm{B})$ and $32^{\circ} \mathrm{C}(\mathrm{C})$.
RPMI 1640 medium at $24^{\circ} \mathrm{C}(\mathrm{p}<0.05)$. RPMI 1640 and RPMI $1640+$ agar $2 \%$ treatments did not show significant difference with exposure time (Figure 1A). However, parasites exposed to RPMI 1640 + agar 2\% medium presented the best results when mortality began to occur later and most of them showed body alterations only on day 19 of observation $(\mathrm{p}<0.05)$. Maximum survival was observed to be 24 days in this medium.

Eleven days of exposure resulted in no difference in parasite survival among the RPMI 1640, RPMI $1640+$ agar 2\%, L-15, and L-15 + agar 2\% media treatments (Figure 1B). RPMI 1640 culture medium showed the best mean survival at $28{ }^{\circ} \mathrm{C}$, with parasites remaining alive for 14 days of exposure. After this period, the parasites showed morphological alterations but remained alive until 28 days.

Until day 4 of observation, no difference in the survival was observed in RPMI 1640, RPMI $1640+$ agar $2 \%$, and $0.9 \% \mathrm{NaCl}$ treatments (Figure 1C). The best survival was obtained at $32{ }^{\circ} \mathrm{C}$ in RPMI $1640+$ agar 2\% medium where the parasites remained active until day 6 of exposure. Most of the parasites began to present morphological changes after this time, with a maximum survival time observed of 10 days.

Additionally, it was observed that eggs released until days 18-19 in the RPMI 1640 and RPMI $1640+$ agar 2\% treatments at $24^{\circ} \mathrm{C}$ and in the RPMI 1640 and RPMI $1640+$ agar $2 \%$ treatments at $28{ }^{\circ} \mathrm{C}$. No egg release was observed for parasites maintained at $32{ }^{\circ} \mathrm{C}$ in all treatments. The results showed that parasites exposed to different culture media were influenced by temperature except for the $0.9 \% \mathrm{NaCl}$ treatment (Figure 2E). 

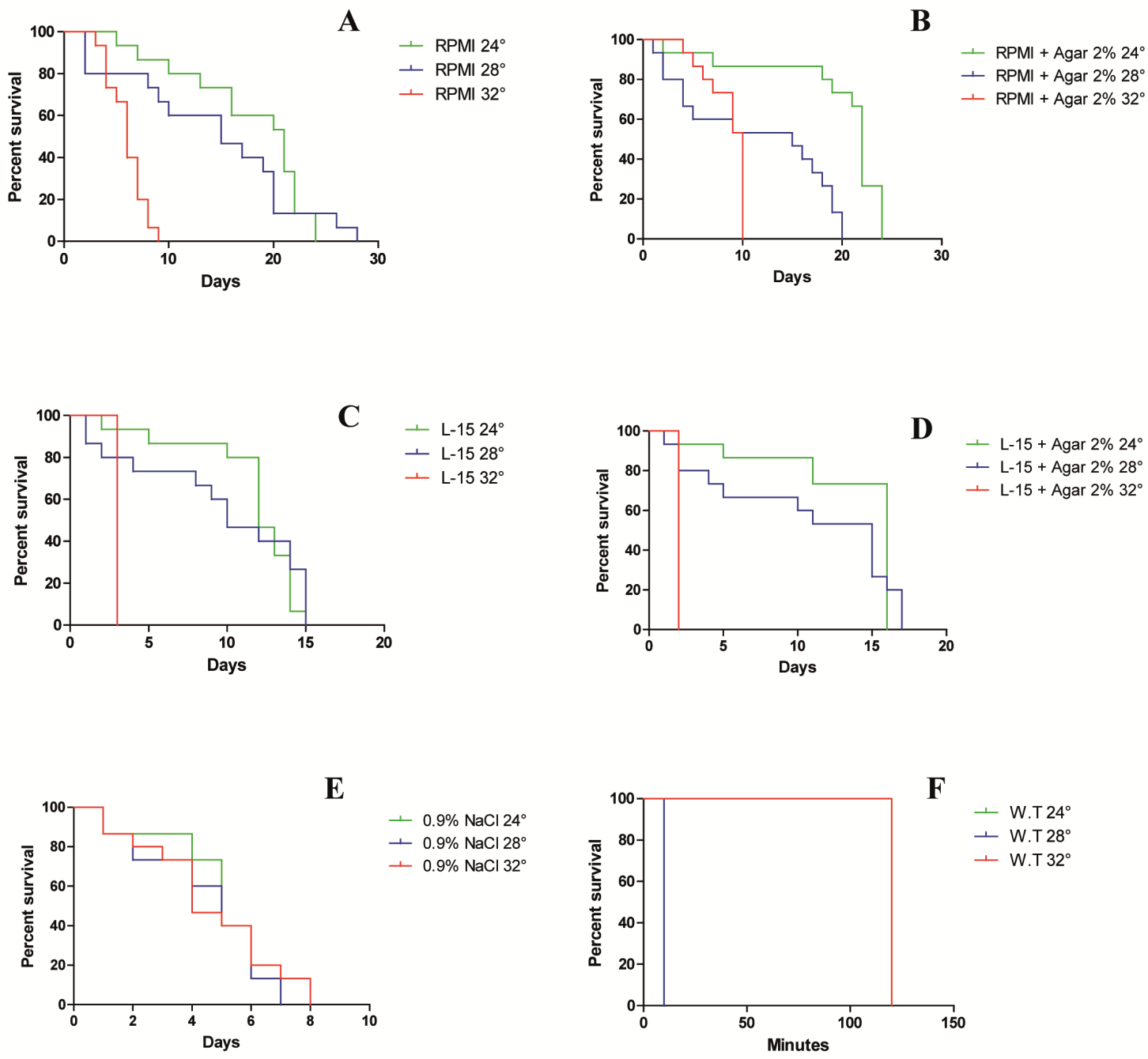

Figure 2. Influence of temperature $\left(24^{\circ}, 28^{\circ}, 32^{\circ}\right)$ on the in vitro survival of Neoechinorhynchus buttnerae exposed to different culture medium. A- RPMI 1640; B- RPMI 1640 + Agar; C- L-15; D- L-15 + Agar; E- 0.9\% NaCl; F- tank water.

\section{Discussion}

Parasites require appropriate culture conditions to survive, such as adequate nutrients, temperature, and incubation conditions. To simulate an ideal host environment, especially under an in vitro culture system, the experimental design must be extremely exigent assuming that all variables can influence the feasibility of parasites (AHMED, 2014).

In the present study, the survival of the acanthocephalans was influenced by temperature and culture medium. However, the body shape suffered more influence from the culture medium than from the temperature, and the lifespan did not exceed 28 days. The RPMI 1640 + agar 2\%, RPMI 1640, L-15, and L-15 + agar $2 \%$ culture media treatments favored parasite survival more than that of the $0.9 \% \mathrm{NaCl}$ and tank water treatments. This can be explained by the presence of glucose in these media, as parasites are unable to use exogenous glucose to maintain their original level of glycogen, thus delaying the reserves of glycogen (DUNAGAN, 1962). This author observed long-term motility of $N$. emydis and $N$. pseudemydis when $0.1 \%$ of glucose was added to a salt solution of Tyrodes (T-BSS) with $\mathrm{NaCl} 0.9 \%$ and $11 \%$ of turtle serum in comparison to the other treatments without glucose.

No indication of parasite growth was observed in the tested treatments because the culture media do not contain protein, lipids, or growth factors, thus indicating the need for supplementation of these products. Nevertheless, even with no supplementation long-term survival is possible as seen in a study by Filipponi et al. (1994) who observed only 3 days survival for Paratenuisentis ambiguus in essential minimum medium without supplementation. The longevity of the parasites in vitro in this study had the objective to their survival for long periods out of 
the host to test effective therapeutic treatments against diseases caused by $N$. buttnerae.

In the present study, egg hatching was observed in RPMI 1640 and RPMI $1640+$ agar 2\% treatments and the parasites did not show any body alterations until day 18 of exposure at $24^{\circ} \mathrm{C}$. The same was observed after 19 days at $28^{\circ} \mathrm{C}$ as was reported in a study by Kawanaka et al. (1983) for the culture of S. japonicum for $48 \mathrm{~h}$ in RPMI 1640 medium supplemented with 10\% fetal calf serum. The authors concluded that 14 amino acids present in the medium (L-arginine, L-cysteine, glycine, L-histidine, L-isoleucine, L-leucine, L-lysine, L-methionine, L-phenylalanine, L-serine, L-threonine, L-tryptophan, L-tyrosine, and L-valine) and choline chloride were essential for the development of S. japonicum eggs. Dunagan (1962) related copula and egg maturation in $N$. emydis and $N$. pseudemydis when maintained in $0.1 \%$ glucose and salt solution of Tyrodes (T-BSS) with $0.9 \% \mathrm{NaCl}$ and $11 \%$ of turtle serum.

The first body shape observations clearly evidenced that the media tested in vitro in the present study maintained the parasites in their normal state. After a period of exposure in the tested solutions, the parasites began to swell. Based on a study by Benesh \& Valtonen (2007), this occurred due to an impaired capacity of osmoregulation as observed in cystacants of Acanthocephalus lucii exposed to $\mathrm{NaCl}, \mathrm{KCl}, \mathrm{CaCl}_{2}, \mathrm{NaHCO}_{3}$ and $\mathrm{MgCl}_{2} \cdot 6 \mathrm{H}_{2} \mathrm{O}$ close to death. In this study, parasite swelling occurred in accordance with the days of exposure and culminated in death.

A longer lifespan was observed in the RPMI 1640 medium treatment under the three temperatures tested than that of the other media treatments, which might be associated with the presence of L-glutamine, an essential amino acid. Based on a study by Lane et al. (1987), L-glutamine has the capacity to maintain the normal polarization of the parasite cuticle because it is a neutral amino acid in physiological conditions. Its transport does not affect the potential of the membrane unless it is linked to and alters the internal load. The presence of L-glutamine was the main factor causing $S$. mansoni resistance to $\mathrm{pH}$ alterations once the membrane $\mathrm{pH}$ was strongly related to the external $\mathrm{pH}$ (LANE et al., 1987).

Most of the metabolized glucose by $S$. mansoni is converted to lactate (SMYTH \& HALTON, 1983). For each mole of lactate produced by anaerobic metabolism, 2 moles of protons are generated (HOCHACHKA \& MOMMSEN, 1983). From this, the glutamine cycle allows the parasite to regulate the intracellular $\mathrm{pH}$ to minimize the proton excess (LANE et al., 1987). Moreover, L-glutamine is important for supplying nitrogen to NAD, $\mathrm{NADPH}$, and nucleotides serving as sources of secondary energy for metabolism (LANE et al., 1987).

The RPMI 1640 medium provided the best survival under the three temperatures tested. Nevertheless, the best results were obtained at $24^{\circ} \mathrm{C}$ and $32^{\circ} \mathrm{C}$. To explain the better results obtained for the RPMI 1640 medium supplemented with agar, Kuss et al. (2007) stated that a semi-solid culture medium creates an environment with low oxygen, which was also supported by Van Cleave \& Ross (1944) who observed a longer lifespan of $N$. emydis in medium with no atmospheric contact.

In the present study, 20 days and 28 days of survival were obtained at $24^{\circ} \mathrm{C}$ and $28^{\circ} \mathrm{C}$, respectively, in RPMI 1640 medium, which was longer survival than that in the study by Brázová et al. (2012) who observed 3 weeks for acanthocephalan A. lucii and the cestode Proteocephalus parasites of Perca fluviatilis in RPMI 1640 medium (Sigma Aldrich ${ }^{\circledR}$ ). In contrast, acanthocephalans maintained in this culture medium at $32{ }^{\circ} \mathrm{C}$ showed only 10 days of survival.

The results demonstrate the influence of low temperatures among the treatments in vitro for $N$. buttnerae. Parasites maintained at $24^{\circ} \mathrm{C}$ presented better survival and uniformity under all media tested, delaying the appearance of body alterations. Our findings corroborate the in vitro studies of Hamers et al. (1991) who determined the feasibility of the acanthocephalan $P$. ambiguus, which is a parasite of Anguilla anguilla that inhabits waters with temperatures close to $20^{\circ} \mathrm{C}$ (PÉREZ et al., 2011). Hamers et al. (1991) evaluated temperatures of $15^{\circ} \mathrm{C}$ and $20^{\circ} \mathrm{C}$ for the culture of these parasites and found that lower temperature kept the parasites alive for 63 days, whereas in the higher temperature they remained alive for 50 days. In vivo observations demonstrated that lowest temperatures are better for parasite survival. Based on a study by Kundu et al. (2015), Channa punctatus increased its degree of infection by acanthocephalan Pallisentis allahabadii as the temperature decreased. Decreased temperature is also related to a reduced immune response of the host, making them more susceptible to parasite infection. Similarly, Koiri \& Roy (2016) reported a higher prevalence of helminths in Clarias batrachus under low temperature conditions.

Although the results herein agree with other studies based on seasonality and abundance of parasites, it is not the unique factor that directly affects their survival. Based on a study by Thomas (2002), the adult parasites life strategy in the host intestine results in decreased abundance during summer suggesting evolutionary pressure. The authors consider that the intestinal environment is particularly hostile, taking into consideration the temperature, immunological system of the host, and intestinal flow.

\section{Conclusion}

The survival rate of $N$. buttnerae was influenced by culture medium, temperature, and morphological alterations dependent on the media tested. The results showed that the RPMI $1640+$ agar $2 \%$ medium treatment at $24^{\circ} \mathrm{C}$ was essential to maintain the body shape of the parasites for greater periods and was responsible for longer intervals with no mortality. High survival rates under these conditions make it possible to develop an effective treatment against diseases caused by this parasite.

\section{Acknowledgements}

This work was supported by Embrapa (MP2 - 02.13.09.003.00.00). The authors would like to thank the National Council of Scientific and Technological Development (CNPq) for financial support to G.T. Jerônimo (MCTI/CNPQ N 001/2016-402434/2016-1, 405224/2017-6 ), M.L. Martins (CNPq 305869/2014-0, 446072/2014-1). They would also like to thank the Coordination for the Improvement of Higher Level Education Personnel (CAPES) for the Master's scholarships to C. Costa, and thanks to Dra. Edsandra Campos Chagas (EMBRAPA Western Amazon) and Dra. Ligia Uribe Gonçalves (National Institute of Amazonian Research - INPA) for the fish donations. 


\section{References}

Ahmed NH. Cultivation of parasites. Trop Parasitol 2014; 4(2): 80-89. http://dx.doi.org/10.4103/2229-5070.138534. PMid:25250227.

Benesh DP, Valtonen ET. Proximate factors affecting the larval life history of Acanthocephalus lucii (Acanthocephala). J Parasitol 2007; 93(4): 742 749. http://dx.doi.org/10.1645/GE-1094R.1. PMid:17918351.

Brázová T, Torres J, Eira C, Hanzelová V, Miklisová D, Šalamún P. Perch and its parasites as heavy metal biomonitors in a Freshwater Enviroment: The case study of the Ružin Water Reservoir, Slovakia. Sensors (Basel) 2012; 12(3): 3068-3081. http://dx.doi.org/10.3390/s120303068. PMid:22736993.

Buron I, James E, Riggs-Gelasco P, Ringwood AH, Rolando E, Richardson D. Overview of the status of heavy metal accumulation by helminths with a note on the use of in vitro culture of adult acanthocephalans to study the mechanisms of bioaccumulation. Neotrop Helminthol 2009; 3(2): 101-110.

Dunagan TT. Studies on in vitro survival of Acanthocephala. Proc Helminthol Soc Wash 1962; 29(2): 131-135.

Filipponi C, Taraschewski H, Weber N. Metabolism of long-chain fatty acids, alcohols and alkylglycerols in the fish parasite Paratenuisentis ambiguus (Acanthocephala). Lipids 1994; 29(8): 583-589. http://dx.doi. org/10.1007/BF02536631. PMid:7990666.

Gettier DA. Studies on the saline requirements of Neoechinorhynchus emydis. Proc Helminthol Soc Wash 1942; 9(2): 75-78.

Gomes ALG, Coelho JG Fo, Silva WV, Oliveira MIB, Bernardino G, Costa JI. The impact of Neoechinorhynchus buttnerae (Golvan, 1956) (Eoacanthocephala: Neochinorhynchidae) outbreaks on productive and economic performance of the tambaqui Colossoma macropomum (Cuvier, 1818), reared in ponds. Lat Am J Aquat Res 2017; 45(2): 496-500. http:// dx.doi.org/10.3856/vol45-issue2-fulltext-25.

Hamers R, Taraschewski H, Lehmann J, Mock D. In vitro study on the impact of fish sera on the survival and fine structure of the eel-pathogenic acanthocephalan Paratenuisentis ambiguus. Parasitol Res 1991; 77(8): 703-708. http://dx.doi.org/10.1007/BF00928686. PMid:1805215.

Hata H, Kojima S. Angiostrongylus cantonesis: In vitro cultivation from the first-stage to infective third-stage larvae. Exp Parasitol 1990; 70(4): 476482. http://dx.doi.org/10.1016/0014-4894(90)90132-V. PMid:2323398.

Hochachka PW, Mommsen TP. Protons and anaerobiosis. Science 1983; 219(4591): 1391-1397. http://dx.doi.org/10.1126/science.6298937. PMid:6298937.

Jerônimo GT, Franceschini L, Zago AC, Silva RJ, Pádua SB, Ventura AS, et al. Parasitos de peixes Characiformes e seus híbridos cultivados no Brasil. In: Tavares-Dias M, Mariano WS. Aquicultura no Brasil: novas perspectivas. 1st ed. São Carlos: Pedro \& João Editores; 2015. p. 283-304.

Jerônimo GT, Pádua SB, Belo MAA, Chagas EC, Taboga SR, Maciel PO, et al. Neoechinorhynchus buttnerae (Acanthocephala) infection in farmed Colossoma macropomum: A pathological approach. Aquaculture 2017; 469: 124-127. http://dx.doi.org/10.1016/j.aquaculture.2016.11.027.

Kawanaka M, Hayashi S, Ohtomo H. Nutritional requirements of Schistosoma japonicum eggs. J Parasitol 1983; 69(5): 857-861. http:// dx.doi.org/10.2307/3281046. PMid:6231359.
Koiri R, Roy B. The seasonal incidence of parasitic helminth infection among the walking catfish, Clarias batrachus of Tripura, India. Ann Parasitol 2016; 62(4): 307-314. PMid:28170203.

Kundu I, Bandyopadhyay PK, Mandal DR. Prevalence of helminth parasites infecting Channa punctatus Bloch, 1793 from Nadia district of West Bengal. J Agric Vet Sci 2015; 8(8): 41-46.

Kuss AV, Kuss VV, Lovato T, Flôres ML. Nitrogen fixation and in vitro production of indolacetic acid by endophytic diazotrophic bacteria. Pesq Agropec Bras 2007; 42(10): 1459-1465. http://dx.doi.org/10.1590/ S0100-204X2007001000013.

Lane CA, Pax R, Bennett J. L-glutamine: an amino acid required for maintenance of the tegumental membrane potential of Schistosoma mansoni. Parasitology 1987; 94(2): 233-242. http://dx.doi.org/10.1017/ S0031182000053919. PMid:3588012.

Leibovitz A. The growth and maintenance of tissue-cell cultures in free gas exchange with the atmosphere. Am J Hyg 1963; 78: 173-180. PMid:14063721.

Lourenço FS, Morey GAM, Pereira JN, Malta JCO. Occurrence of Neoechinorhynchus (Neoechinorhyncus) buttnerae Golvan, 1956 (Acantocephala: Neoechinorhynchidae) in Colossoma macropomum (Cuvier, 1818) (Characiformes: Serrasalmidae) from a fish farm in the Brazilian Amazon. Folia Amaz 2017; 26(1): 1-8.

Malta JCO, Gomes AL, Andrade SMS, Varella AMB. Infestaçóes maciças por acantocéfalos, Neoechinorhynchus buttnerae Golvan, 1956, (Eoacanthocephala: Neoechinorhynchidae) em tambaquis jovens, Colossoma macropomum (Curvier, 1818) cultivados na Amazônia Central. Acta Amaz 2001;31(1): 133-143. http://dx.doi.org/10.1590/1809-43922001311143.

Matos LV, Oliveira MIB, Gomes ALS, Silva GS. Morphological and histochemical changes associated with massive infection by Neoechinorhynchus buttnerae (Acanthocephala: Neoechinorhynchidae) in the farmed freshwater fish Colossoma macropomum Cuvier, 1818 from the Amazon State, Brazil Parasitol Res 2017; 116(3): 1029-1037. http://dx.doi.org/10.1007/ s00436-017-5384-3. PMid:28124738.

Nicholas WL, Grigg H. The in vitro culture of Moniliformis dubius (Acanthocephala). Exp Parasitol 1965; 16(3): 332-340. http://dx.doi. org/10.1016/0014-4894(65)90055-X. PMid:14324306.

Oliveira AM, Val AL. Effects of climate scenarios on the growth and physiology of the Amazonian fish tambaqui (Colossoma macropomum) (Characiformes: Serrasalmidae). Hydrobiologia 2017; 789(1): 167-178. http://dx.doi.org/10.1007/s10750-016-2926-0.

Pérez L, Peñaranda DS, Dufour S, Baloche S, Palstra AP, Van Den Thillart GEEJM, et al. Influence of temperature regime on endocrine parameters and vitellogenesis during experimental maturation of European eel (Anguilla anguilla) females. Gen Comp Endocrinol 2011; 174(1): 51-59. http://dx.doi.org/10.1016/j.ygcen.2011.08.009. PMid:21871894.

Polzer M, Taraschewski H. Proteolytic enzymes of Pomphorhynchus laevis and in three other acanthocephalans species. J Parasitol 1994; 80(1): 45 49. http://dx.doi.org/10.2307/3283343. PMid:8308657.

Poulin R, Morand S. Parasite biodiversity. Washington: Smithsonian Books; 2004

Quesada SP, Paschoal JAR, Reyes FGR. Considerations on the aquaculture development and on the use of veterinary drugs: special issue for fluoroquinolones - A review. J Food Sci 2013; 78(9): 1321-1333. http:// dx.doi.org/10.1111/1750-3841.12222. PMid:23909512. 
Reverter M, Bontemps N, Lecchini D, Banaigs B, Sasal P. Use of plant extracts in fish aquaculture as an alternative to chemotherapy: current status and future perspectives. Aquaculture 2014; 433: 50-61. http:// dx.doi.org/10.1016/j.aquaculture.2014.05.048.

Santos CP, Machado PM, Santos EGN. Acanthocephala. In: Pavanelli GC, Takemoto RM, Eiras JC. Parasitologia: peixes de água doce. Maringá: Eduem; 2013. p. 353-370.

Schramlová J, Blazek K, Marhoul Z, Singhvi A. Ultrastructure of Taenia saginata oncospheres cultivated in artificial media. Folia Parasitol (Praha) 1984; 31(3): 247-251. PMid:6479753.
Smyth JD, Halton DW. The adult-general metabolism. In: The physiology of Trematodes. 2nd ed. Cambridge: Cambridge University Press; 1983. p. 64-84.

Thomas JD. The ecology of fish parasites with particular reference to helminth parasites and their salmonid fish hosts in Welsh rivers: a review of some of the central questions. Adv Parasitol 2002; 52: 1-154. http:// dx.doi.org/10.1016/S0065-308X(02)52011-X. PMid:12521260.

Van Cleave HJ, Ross EL. Physiological responses of Neoechinorhynchus emydis (Acanthocephala) to various solutions. J Parasitol 1944; 30(6): 369-372. http://dx.doi.org/10.2307/3272688. 